Desimir Bošković*

UDK 659.13/.16:338.48>(497.5-3 Istra)

Ana Težak*

Preliminary paper

Darko Saftić*

Prethodno priopćenje

\title{
MEDIA IN COLLECTING INFORMATION ON TOURISM DESTINATIONS AND SOCIODEMOGRAPHIC CHARACTERISTICS
}

\begin{abstract}
Media choice is an element of promotion mix. Its purpose reflects in creation of first impression i.e. image of a tourism destination and is directed toward a certain profile of tourists. Media and sociodemographic characteristics of tourists are among the most important elements in creating image of a particular tourism destination. The main purpose of this paper is to determine relationship between sociodemographic characteristics of tourists and media choice in obtaining information on tourism destination. The data on media choices was collected as a part of a research on tourists' interests for consumption of organic food, which was conducted from August through September 2008. Data was processed using chi-square test.
\end{abstract}

JEL: M31, $O 18$

Keywords: media choice, tourism destination, sociodemographic characteristics of tourists, Istria County

\section{INTRODUCTION}

Tourism is one of the economic activities characterized as being largely dependent on the discretional decision of their consumers i.e. tourists. Consumers have a wide range of choices among the possibilities of maximizing their personal satisfaction 1) by choosing among various tourism destinations available or 2) by choosing vacation and entertainment outside the tourism consumption domain, for example, by buying a TV set or by participating in cultural or other events (Croy, 2004). Present consumers are strongly aware of the efforts made by advertising agents and the result of that is difficulty in accepting promotional messages. Moreover, when planning tourism promotional campaigns, "what has to be stressed is a series of issues as to which factors influence customers' opinion, how familiar customers are with the trademark and how they relate to promotion activities" (Morgan, Pritchard, 2001:21). In such a situation the accent is on the importance of image and perception as factors defining the final choice of the consumer among the whole spectrum of options offered. In this process, what should be taken into account is the growing role of the media in creating and spreading among the customers i.e. tourists the image and the perception of a tourism destination, an aspect which is very important for tourism management within both a tourism destination and a company (Croy, 2004).

The literature on tourism destination image indicates three the most important factors which appear when tourists do not visit a particular destination nor experience it previously: tourist motivation, sociodemographic characteristics and different information sources. According to Baloglu and McCleary, "information sources represent stimulus variables, whereas motivations and sociodemographic stand for consumer characteristics", (1999:870).

\footnotetext{
${ }^{*}$ Kontakt podaci: Zavod za turizam, Institut za poljoprivredu i turizam, Karla Huguesa 8, 52440 Poreč desimir@iptpo.hr

tezak@iptpo.hr

darkos@iptpo.hr
} 
Stimulus factors are those deriving from external stimulation sources, physical objects and previous experiences, while personal factors are consumers' social and psychological characteristics (see Figure 1).

\section{Figure 1}

\section{A General Framework of Destination Image Formation}

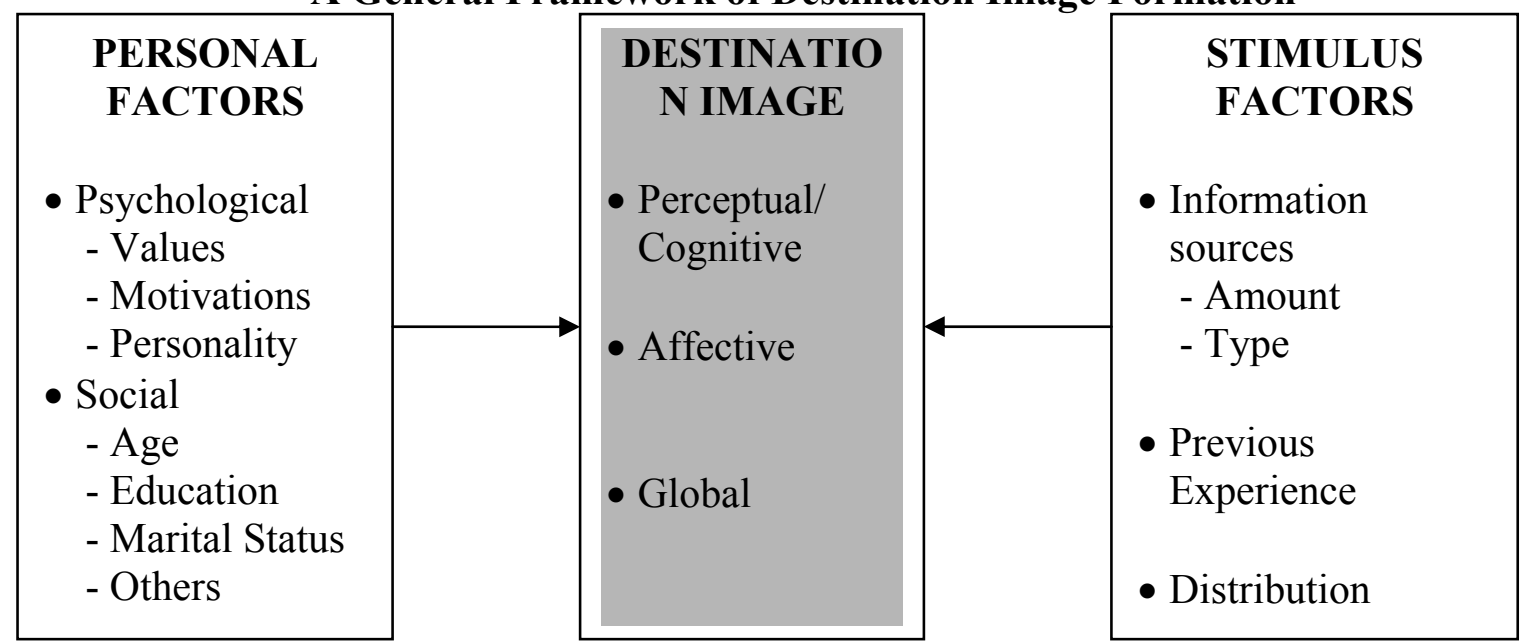

Source: Baloglu, McCleary, 1999:870

The theoretical model of choosing a tourist destination treats marketing variables and information sources as the force which influences perceptual/cognitive evaluations of the image construct. Perceptual and cognitive evaluations of characteristics and beliefs concerning the destination are carried out through external factors: 1) symbolic stimuli which comprise various information sources and 2) social stimuli, i.e. friends' or relatives' recommendation or oral recommendation, (Woodside, Lysonski, 1989).

Promotion through various media is aiming at consumer's different emotional and cognitive processes, which is why it is important that the influence of various communication channels are understood by tourism marketing organizations, so that high-quality strategic decisions can be made concerning promotion development and choice of information channel, (Kim, Hwang, Fesenmaier, 2005).

The image of certain tourism destinations is related to choosing of a particular tourism destination, so destination and tourism managers must understand the significance of a destination's image and the role of media in it. Strategies for a tourism destinations must be develop and implement by making image management theirs integral part. In order to obtain the best possible image management, it is necessary to identify possible information sources through which tourists perceive the image, as well as the level of influence each source has on the same tourists to choose the most efficient ones (Croy, 2004).

\section{LITERATURE REVIEW}

Many research studies on effects of promotion in tourism are based on the connection between different attitudes and behavioural components opposed to visits, without taking into consideration relations between indirect variables (Butterfield, Deal, Kubursi, 1998). Other research studies on tourism promotion proved that the promotional effect is not restricted to only the present visits but expanded to a number of psychological effects and changes in the consumers' behaviour, including the creation of a positive image of a destination and the stimulation of preferences concerning the same destination, which may in the long term lead 
to paying a visit to the destination (Bojanic, 1991; according to Kim, Hwang, Fesenmaier, 2005). Seigel and Ziff-Levine (1990, in McWilliams and Crompton, 1997) defined the advertising tracking model in order to show the influence of media on the choice of tourism services. The model assumes that potential visitors can change their mind/can be converted and choose a tourist service only because exposed to ads and to the promotion of the image (see Figure 2).

\section{Figure 2}

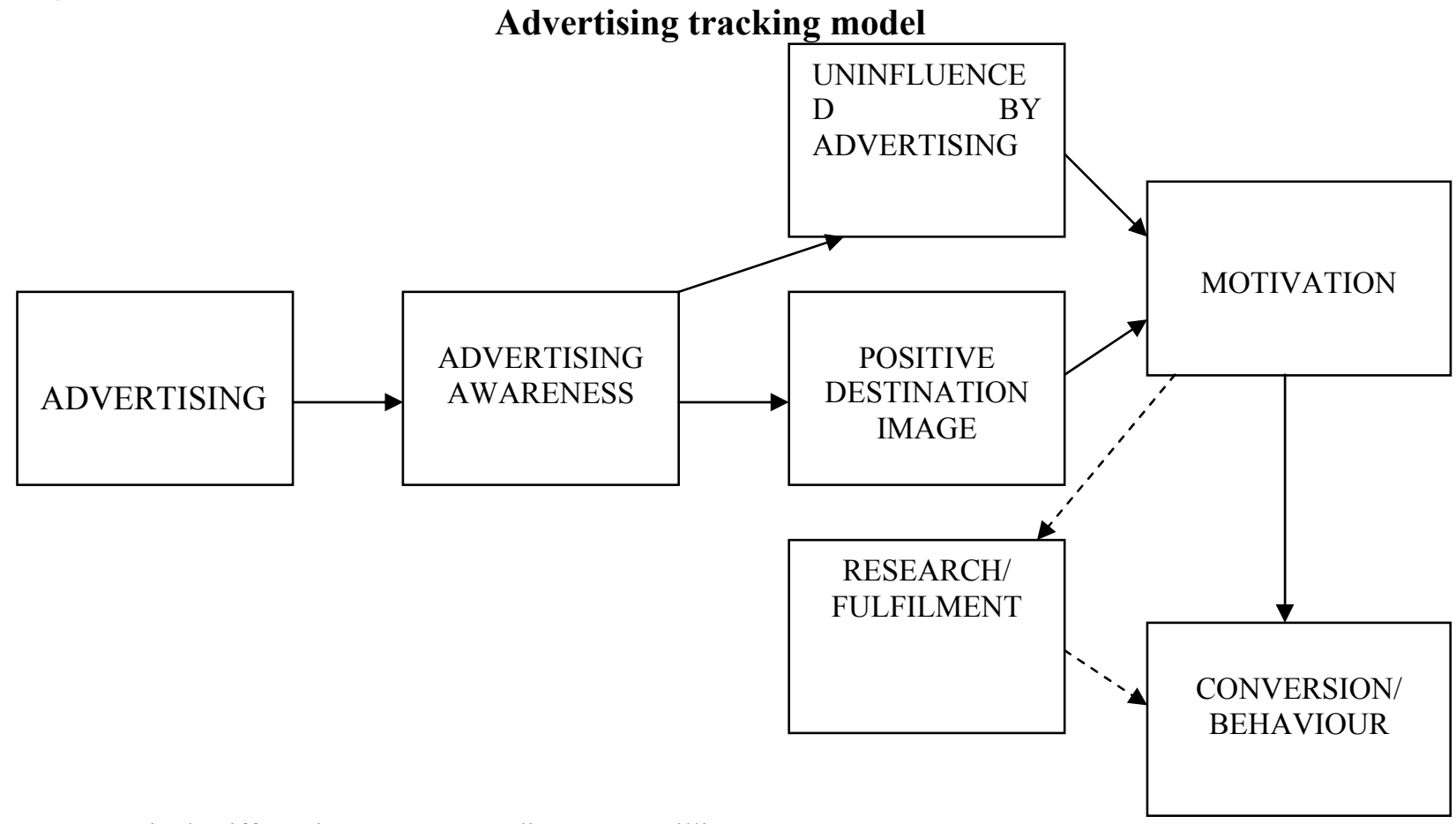

Source: Seigel, Ziff-Levine, 1990; according to McWilliams, Crompton, 1997:129

Tourism global market varies according to certain elements, as geographic area, social and demographic characteristics etc. (Pike, 2008), so when planning the promotion of a tourism destination, it is necessary to choose adequate information sources i.e. media. This refers to those information sources that are the most commonly used. Choosing the channel as medium of information is one of the most critical moments in tourism promotion since different channels and media have certain advantages and disadvantages in delivering various types of promotional messages. Even the best promotion performance will not be efficient if the wrong medium is chosen, (Morgan, Pritchard, 2001: 55). Marketing communication in tourism uses different information sources, depending on the type of the product, the purpose of the campaign, the market's characteristics (Horner, Swarbrooke, 2007). For successful marketing communication appropriate media must be used.

Information sources presenting tourism destination can influence the consumers' decisionmaking process starting for the choice of the very tourism destination to the consumption within the destination. Promotion of tourism destination must be effective and the evaluation of its effects has, so far, focused mainly on how much a promotional campaign "stimulates" visits to a certain destination.

Information sources can be divided into organic and induced, (Gartner, 1993; according to Croy, 2004). Organic are those sources that do not involve personal interests in promoting a tourism destination (for example, books, news, films or visits to the destination), while in the category of induced sources there are different instruments for spreading the tourism destination promotional messages intended for the target group of tourists (for example, 
brochures, ads, flyers, catalogues, video clips, Internet, etc.). The image of a tourism destination is formed through induced factors if potential tourists have not visited previously a given destination (Gartner, 1989; according to Križman Pavlović, Belullo, 2008).

In gathering information printed materials have been used for centuries. In the computerisation era there have been some changes in the process (Nazim, 2008). Today Internet is becoming a very important information channel for promotion of tourism destinations (Govers, Go, 2003). This is reimbursed by the fact that websites are a convenient medium for uploading photographs that are considered the most important means for the promotion of a tourism destination taking more than 75 per cent of total space in brochures (Jenkins, 1999; according to MacKay, Smith, 2005). However, there are some disadvantages of using the Internet: there is too much irrelevant information, as well as the possibility of finding unwanted or awkward information, (Bubaš and Kermek, 2000), the necessity of having certain skills, the absence of personal contact and communication, the lack of possibility of recognizing consumers' reactions and the possibility of facing distrust among some tourists concerning online payments and possible stealing of personal data.

The individuals' personal characteristics, such as gender, age, occupation, education and social class, are internal inputs that influence the perceptions of destinations (Baloglu and McCleary, 1999; Woodside, Lysonski, 1989; Um \& Crompton, 1990; Stabler, 1995). According to Baloglu and McCleary, «most image formation and destination selection models have incorporated sociodemographic variables as conventional consumer characteristics influencing perceptions of objects, products, and destinations. Although such variables as age, education, income, gender, occupation, and marital status have all been suggested as influencing perceptions and images, age and education appear to be major determinants of image», (1999:875). Beerli and Martin summarized the results of previous empirical researches and came to the conclusion that the tourist's country of origin, gender, age and social class significantly influence the perceptual/cognitive and affective components of the perceived image of the tourism destination (2004:627). Sociodemographic characteristics influence the way in which one searches for, evaluates and uses information sources (Uysal, Fesenmaier, 1993). Information sources and sociodemographic characteristics of individuals both influence formation of image, so it can logically be assumed that there is an interaction between information sources and sociodemographic characteristics of tourists.

The aim of this paper is to establish if the selected information source is independent from sociodemographic characteristics.

\section{METHODOLOGY}

A study focused on tourists' behaviour and organic food was conducted from August through September 2008. In this study the target population included those tourists who visited six tourism towns in Istria County: Rabac, Pula/Medulin, Rovinj, Poreč and Umag. These sites were visited by more than $50 \%$ of tourists visiting Istria County in 2007 (Istria Tourist Board, 2007). Survey was carried out in 18 hotels and luxurious villas through a selfadministered questionnaire. Tourists were approached by trained researcher and asked to participate in the survey. Researcher then explained the purpose of the survey and stressed the fact that the survey was anonymous. Tourists younger than 16 years of age were excluded from the survey. Convenient sample was used.

For the purpose of gathering data, the questionnaire was constructed. It consisted of 16 questions divided in three sections. The first set comprises questions concerning the purchase of ecological food in the country of arrival and aimed at establishing the habit of buying ecological food. The second set of questions was focused on tourists' stay in Istria County and their interest in purchasing ecological food while on vacation. The last set of questions 
comprised tourists' sociodemographic characteristics (country of origin, age, gender, education, profession, income), their interest in staying in rural areas during their vacation, and ways of gathering information on Istria County as tourism destination. Questionnaire was originally designed in Croatian and then translated into following languages: English, German, Italian, Russian and Slovenian.

Chi-square test was applied to determining whether the used media and sociodemographic characteristics of tourists are statistically independent.

Sociodemographic characteristics taken into analysis were: age group, gender, education level, profession, country of origin and income. Information sources were classified as follows: 1) travel agencies, 2) Internet, 3) printed publications, newspapers and TV, 4) catalogues and brochures, 5) on the spot, 6) friends'/relatives' recommendations. 


\section{RESULTS}

A total of 1300 questionnaires were distributed and collected. The final number of usable questionnaires was 1028 reaching a full response rate of $79 \%$ (excluding the cases with missing answers). Table 1 illustrates the sociodemographic and travelling characteristics of the responders.

Table 1

Sociodemographic and travelling characteristics of the responders

\begin{tabular}{|c|c|c|c|}
\hline \multirow{2}{*}{\multicolumn{2}{|c|}{ Social and demographic indicator }} & \multicolumn{2}{|c|}{ Interviewees } \\
\hline & & \multirow{2}{*}{$\begin{array}{r}\text { Frequency } \\
99\end{array}$} & \multirow{2}{*}{$\%$} \\
\hline \multirow{5}{*}{ Age group } & $16-24$ & & \\
\hline & $25-34$ & 196 & 19.07 \\
\hline & $35-44$ & 268 & 26.07 \\
\hline & $45-54$ & 266 & 25.88 \\
\hline & $55+$ & 199 & 19.36 \\
\hline \multirow[t]{2}{*}{ Gender } & Female & 591 & 57.49 \\
\hline & Male & 437 & 42.51 \\
\hline \multirow[t]{4}{*}{ Education level } & Elementary school & 92 & 8.95 \\
\hline & Secondary school & 308 & 29.96 \\
\hline & College/BA & 501 & 48.74 \\
\hline & $\mathrm{MA} / \mathrm{PhD}$ & 127 & 12.35 \\
\hline \multirow[t]{8}{*}{ Profession } & Private entrepreneur & 144 & 14.01 \\
\hline & Manager & 191 & 18.58 \\
\hline & Clerk & 314 & 30.54 \\
\hline & Worker & 65 & 6.32 \\
\hline & Student/pupil & 55 & 5.35 \\
\hline & Pensioner & 80 & 7.78 \\
\hline & Unemployed & 10 & 0.97 \\
\hline & Other & 169 & 16.44 \\
\hline \multirow[t]{6}{*}{ Country of origin } & Austria & 143 & 13.88 \\
\hline & United Kingdom & 126 & 12.30 \\
\hline & Italy & 164 & 15.93 \\
\hline & Germany & 152 & 14.83 \\
\hline & Russia & 305 & 29.65 \\
\hline & Other & 138 & 13.41 \\
\hline \multirow[t]{6}{*}{ Income } & Up to $€ 500$ & 40 & 3.92 \\
\hline & $€ 500-1,000$ & 143 & 13.4 \\
\hline & $€ 1000-2000$ & 225 & 21.89 \\
\hline & $€ 2000-5000$ & 203 & 19.72 \\
\hline & over $€ 5000$ & 63 & 6.10 \\
\hline & No specification & 354 & 34.44 \\
\hline
\end{tabular}

Source: Institute of Agriculture and Tourism, Department of Tourism, Questionnaire - Ecological food 2008, authors' analysis.

More than half of interviewees were 35 to 54 years old, while the majority of them were between 35 and 44 years of age. Most interviewees were female. Almost half of the people interviewed have a two-year or a traditional four-year Bachelor degree. Most interviewees were clerks, followed by those who work as managers. Most interviewees were from Russia, 
whereas there was almost no difference in the number of tourists from Austria, Italy, Germany and the UK. Most interviewees earn between 1000 and 2000 Euros.

There are different ways to obtain information about a tourism destination. The very choice depends on sociodemographic characteristics of individuals. It is necessary to determine which sociodemographic characteristics are statistically significant related to media choice so that adequate promotional activities can be applied.

Age, education level, income, country of origin and profession were significantly related to different kind of information sources while gender proved not to be significantly related to different types of media (Table 2). Country of origin was significantly related to every media choice, while other significantly related sociodemographic variables were related to certain media.

Table 2

\begin{tabular}{|c|c|c|c|c|}
\hline \multicolumn{5}{|c|}{ Media choice and tourists' social and demographic features } \\
\hline Variable & $\chi^{2}$ & df & $\mathrm{CC}$ & $\mathbf{P}$ \\
\hline \multicolumn{5}{|l|}{ Travel agency } \\
\hline Age & 17.563 & 4 & 0.118 & 0.002 \\
\hline Education level & 13.645 & 3 & 0.106 & 0.003 \\
\hline Income & 19.099 & 4 & 0.175 & 0.001 \\
\hline Country of origin & 91.471 & 5 & 0.259 & 0.000 \\
\hline \multicolumn{5}{|l|}{ Internet } \\
\hline Age & 32.522 & 4 & 0.160 & 0.000 \\
\hline Profession & 23.649 & 7 & 0.139 & 0.001 \\
\hline Country of origin & 21.291 & 5 & 0.129 & 0.001 \\
\hline \multicolumn{5}{|l|}{ Catalogue/brochures } \\
\hline Age & 23.222 & 4 & 0.135 & 0.000 \\
\hline Education level & 9.652 & 3 & 0.089 & 0.022 \\
\hline Income & 12.893 & 4 & 0.145 & 0.012 \\
\hline Country of origin & 162.539 & 5 & 0.337 & 0.000 \\
\hline \multicolumn{5}{|l|}{ Printed publications, TV } \\
\hline Age & 10.311 & 4 & 0.091 & 0.036 \\
\hline Country of origin & 33.403 & 5 & 0.160 & 0.000 \\
\hline \multicolumn{5}{|c|}{ At destination - on the spot } \\
\hline Age & 10.996 & 4 & 0.094 & 0.027 \\
\hline Education level & 14.066 & 3 & 0.108 & 0.003 \\
\hline Country of origin & 37.085 & 5 & 0.169 & 0.000 \\
\hline \multicolumn{5}{|c|}{ Information from relatives and friends } \\
\hline Country of origin & 15.037 & 5 & 0.108 & 0.010 \\
\hline
\end{tabular}

Source: Institute of Agriculture and Tourism, Department of Tourism, Questionnaire-ecological food 2008, authors' analysis

Travel agency as an information source was chosen by half of the responders from Russia and every fifth tourist from the UK, and by half of the responder between 16 and 24 years of age. The majority of responders with obtained higher level of education decided to use travel agencies as a way of obtaining information. Two-thirds of responders with an income of $€ 500$ obtained information in a tourist agency, and so has half of that responder who earned between $€ 500$ and $€ 1000$. With the increase in income, there is a decrease in the number of persons who decided to obtain information about their tourism destination in a travel agency. 
Internet as a source of information was the most frequently chosen by responders between 25 and 34 years of age. Internet usage decreased by increase in age. More than $38 \%$ of responders who stated that they were managers as well as more than $36 \%$ of employees used Internet for obtaining information about Istria County. German tourists were more likely to choose Internet than others.

Catalogues and brochures were mainly chosen by responders older than $54(23 \%)$. Responders with lower education level i.e. primary and secondary school $(21 \%)$ and with an income over $€ 5,000$ were more likely to choose catalogues and brochures than those with higher education level and lower levels of income. Britons (38\%) were more likely to choose this kind of media.

In general responders did not prefer to use printed media and TV as well as obtaining information at the destination. Printed media and TV was mostly used by German tourists $(12 \%)$ and those tourists older than $54(9 \%)$. Obtaining information at the destination was mostly preferred by responder between 35 and 44 years of age $(8 \%)$ and those tourists who obtained the most high school degree (8\%). Tourists arriving from Austria (10\%) or Germany $(9 \%)$ were more likely to obtain information about Istria at the arrival at the destination compared to other nation.

Recommendation from relatives and friends were important for tourists coming from Germany (37\%) and Austria (35\%).

\section{DISCUSSION AND CONCLUSION}

Russian and UK tourists, younger responders, responder who obtained higher level of education and those tourists with personal net income up to $1.000 €$ per month were more likely to use travel agency as a way of getting the information about tourism destination. These results suggest that promoting Istria County at the tour operators and travel agencies may result in the increase of these segments of tourists.

Internet was mostly used by younger responders, managers and employees as well as those responders arriving from Germany. It may be concluded that Internet will play an important role in the process of choosing tourism destination in the future so it is advisable to use Internet in promotion activities.

Catalogues and brochures were more frequently chosen by older tourists and responders with lower level of education. These results suggest that this form of media is getting obsolete which can be expected in age of computerisation.

Printed media and TV as well as getting information in the destination were not preferred ways of obtaining information. Printed media and TV was mostly chosen German responders and older tourists, while middle-aged and lower educated responders, mostly from Austria and Germany decided on getting information at the destination. These results suggest printed media and TV are not important media in choosing Istria County as tourism destination and it is advisable to invest less in this kind of channel than others. Tourists like to know where they are going and what they can expect there, so getting information at the destination was probably important to those responders who already visited this tourism destination.

Recommendations from relatives and friend were mostly important to responders coming from Austria and Germany, suggesting that good recommendations can result in the increase of tourists' arrivals from these countries which have the highest proportion in total tourists' arrivals in Istria County.

Marketing communication and types of media play a vital role in selecting tourism destination. Tourists like to be informed about the offer in a certain tourism destination. Thus it is possible to obtain information about marketing influence and return on promotion spending, in addition to details concerning channels and sources of information that change 
over time and according to trends. The obtained results of the research can be useful for the organization of certain promotional activities according to tourists' sociodemographic characteristics and market segments. The conclusions of this paper can help tourist organizations, hospitality management, tourist boards and travel agencies as a useful data source on the basis of which it is possible to try to improve, by planned corrections of promotional actions in chosen information media, the perception of their promotional messages and the image of the tourism destination of Istria within all relevant market segments.

There are some limitations of this study. Since convenient sample as a method of collecting data was used obtained results may not be generalized to the overall Istria County's tourism market. This paper examined only usage of certain kind of media, but not their importance. It was assumed that those types of media that were more frequently selected were more important form those that were not. Further research on determining importance of certain kind of information sources should be conducted.

\section{REFERENCES}

1. Baloglu, S., McCleary, K.W., (1999), “A model of destination image formation”, Annals of Tourism Research, 26 (4):868-897.

2. Beerli, A., Martin, J.D., (2004), "Tourists' characteristics and the perceived image of tourist destinations: a quantitative analysis - a case study of Lanzarote, Spain", Tourism Management, 25 (5):623-636.

3. Bubaš, G., Kermek, D., (2000), "Komparativna procjena Interneta u odnosu na tisak i televiziju”, Medijska istraživanja, 6 (1):109-123.

4. Butterfield, D.W., Deal, K.R., Kubursi, A.A., (1998), "Measuring the Returns to Tourism Advertising", Journal of Travel Research, 37 (1):12-20.

5. Croy, W.G., (2004), "Teaching Tourism, Image and Media Relationships", International Tourism and Media Conference Proceedings, (Melbourne:Tourism Research Unit, Monash University):24-38.

6. Govers, R., Go, F.M., (2003), "Deconstructing destination image in the information age", Information Technology \& Tourism, 6:13-29.

7. Kim, D.Y., Hwang, Y.H., Fesenmaier, D.R., (2005), "Modeling tourism advertising effectiveness", Journal of travel research, 44 (1):42-49.

8. Križman Pavlović, D., Belullo, A., (2007), "Internet - An Agent of Tourism Destination Image Formation: Content and Correspondence Analysis of Istria Travel Related Websistes", Proceedings of the 4th International Conference Global Challenges for Competitiveness: Business and Government Perspective, (Pula: Juraj Dobrila University of Pula, Department of Economics and Tourism):541-556.

9. MacKay, K., Smith, M.C., (2006), "Destination advertising: Age and Format Effects on Memory", Annals of Tourism Research, 33 (1):7-24.

10. McWilliams, E.G., Crompton, J.L., (1997), "An expanded framework for measuring the effectiveness of destination advertising", Tourism Management, 18 (3):127-137.

11. Morgan, N., Pritchard, A. (2001), Advertising in Tourism and Leisure, (Oxford: Butterworth-Heinemann)

12. Nazim, M., (2008), 'Information searching behaviour in the Internet age: A users' study of Aligarh Muslim University", The International Information \& Library Review, 40:73-81.

13. Pike, S., (2008), Destination Marketing: An Integral Marketing Communication Approach, (Oxford: Butterworth-Heinemann) 
14. Stabler, M. J., (1995), "The image of destination regions: Theoretical and empirical aspects" (p.133-159.) in Goodall, B., Ashworth, G., (Eds.), Marketing in tourism Industry: The Promotion of destination regions London: Routledge)

15. Swarbrooke, J., Horner, S., (2007), Consumer Behaviour in Tourism, (Oxford: Butterworth-Heinemann)

16. Um, S., Crompton, J. L., (1992), "The roles of perceived inhibitors and facilitators in pleasure travel destination decisions", Journal of Travel Research, 30 (3):18-25.

17. Uysal, M., Fesenmaier, D.R., (1993), Communication and channel systems in tourism marketing, (Binghamton: The Haworth Press)

18. Woodside, A., Lysonski, S. (1989), "A general model of traveller destination choice", Journal of Travel Research, 27 (4):8-14.

\section{NAČINI INFORMIRANJA O TURISTIČKOJ DESTINACIJI SA SOCIODEMOGRAFSKOG ASPEKTA}

\section{SAŽETAK}

Odabir medija je element promocije. Svrha mu je stvaranje prvog utiska, odnosno imidža turističke destinacije te je stoga usmjeren na određen profil turista. Mediji i socio-demografske karakteristike turista su među najvažnijim elementima u stvaranju imidža određene turističke destinacije. Osnovni cilj ovog rada je određivanje veze između socio-demografskih karakteristika turista i odabira medija pri dobivanju informacija o turističkoj destinaciji. Podaci o odabiru medija su prikupljeni u sklopu istraživanja interesa turista za konzumiranjem organske hrane koje je provedeno u kolovozu i rujnu 2008. Podaci su obrađeni hi-kvadrat testom.

Ključne riječi: odabir medija, turistička destinacija, socio-demografske karakteristike turista, Istarska županija 